\title{
INCOME TAX ASSIGNMENT UNDER THE ETHIOPIAN CONSTITUTION: ISSUES TO WORRY ABOUT
}

\author{
Taddese Lencho* \\ If you can look into the seeds of time \\ And say which grain will grow, and which will not \\ William Shakespeare, Macbeth, Act 1, Scene 3, lines 58-59
}

\begin{abstract}
The revenue provisions of the Ethiopian Constitution are striking on a number of levels. By and large, the revenue provisions do not evince conformity with what the theories of fiscal federalism generally prescribe in the area of assignment of revenue powers. In addition, the revenue provisions of the Ethiopian Constitution are more detailed than their counterparts elsewhere. And, the Ethiopian Constitution departs from the assignment formula set for expenditure powers and prescribes a special procedure for assignment of 'undesignated taxes'. These features of the Ethiopian Constitution raise a number of questions and concerns. This article uses the income tax assignment in the Ethiopian Constitution to highlight some of these questions and concerns. There is ample evidence to show that the assignment formula adopted by the Constitution, indeed its predecessor - the 1992 law - was motivated by the desire to divide the power of taxation over existing taxes in Ethiopia rather than to reinvent the wheel. However, there might be a tension between the formula the Constitution adopts to assign tax powers and the prescriptions of the theories of fiscal federalism. The article explores the implications of this assignment.
\end{abstract}

\section{Key words:}

Income tax, Ethiopian Constitution, fiscal federalism, revenue assignment, global income tax, schedular income tax

* Lecturer in Law, Addis Ababa University, Faculty of Law; LL.B (AAU); LL.M (University of Michigan Law School, Ann Arbor); PhD Candidate, University of Alabama Law School; I am grateful to all those who gave constructive comments on the earlier drafts of this article. 


\section{Introduction}

With the exception of the brief federal experiment with Eritrea between 1952 and 1962, modern Ethiopia operated as a heavily centralized state until the Dergue was removed from power in 1991 by a coalition of forces under the Ethiopian Peoples Revolutionary Democratic Front (EPRDF), the ruling party in Ethiopia. ${ }^{1}$ A transitional period Charter was signed immediately thereafter, which put Ethiopia on a course of a federal-type structure. A law was passed in 1992 to distribute revenue powers between the central government and the regional governments. ${ }^{2}$ This experiment with fiscal federalism culminated with the promulgation of the Constitution in 1995, which is the basic law that now regulates fiscal as well as other relations between the federal government and the regional governments.

The fiscal provisions of the 1995 Constitution reflect the political compromise that was reached by the dominant forces at the time of the writing of the Constitution. However, the assignment formula adopted by the Constitution creates a tension between what was politically and historically desirable at the time of the adoption of the Constitution and what might transpire in the future, particularly because of the unusual specificity of the Constitution in this regard and because the Constitution, in its revenue provisions, seems to disregard the importance of tax powers as instrumentalities of economic policies of re-distribution of income and wealth and stabilization.

1 The ruling party EPRDF is a coalition of four major parties - Tigray Peoples' Liberation Front (TPLF), Amhara National Democratic Movement (ANDM), Oromo People's Democratic Organization (OPDO), and Southern Ethiopian Peoples' Democratic Front (SEPDF). These parties operate in the four major regions of the federation, including the capital, Addis Ababa. In addition, the EPRDF has its affiliates in all the other regions - the Afar People's Democractic Organization in Afar Regional State, the Somali People's Democratic League (SPDL) in Somali Regional State; the Gambella Peoples' Democratic Front (GPDF) in Gambella Regional State, the Beneshangul-Gumuz Peoples' Democratic Unity Front (BGPDUF) in Beneshangul-Gumuz Regional State, and the Harari National League (HNL) in Harari Regional State; see Assefa Fiseha, "Theory versus Practice in the Implementation of Ethiopia's Ethnic Federalism," in David Turton (2006, ed.). Ethnic Federalism: the Ethiopian Experience in Comparative Perspective, East African Studies, Addis Ababa University Press, Addis Ababa, pp. 156-157; Eshetu Chole, 'Keynote Address', and 'Issues of Vertical Imbalance in Ethiopia's Emerging System of Fiscal Decentralization', in Eshetu Chole (ed.,1994), Fiscal Decentralization in Ethiopia, Addis Ababa University Press, pp. ii, 167.

${ }^{2}$ Proclamation No. 33/1992, a Proclamation to Define the Sharing of Revenue Between the Central Government and the National/Regional Self Governments, Negarit Gazetta, 52 ${ }^{\text {nd }}$ Year, No. 7. 
The assignment of income tax powers is a good example of the specificity of the Ethiopian Constitution. What the revenue provisions of the Ethiopian Constitution did was to divide the different income tax sources into smaller slices and share them between the federal government and the regional governments. It is known that the existing income tax system in Ethiopia is based (as has always been) on sources of income rather than the individual taxpayer who earns the income. All that the revenue provisions did was take these sources of income as they were recognized at the time of the writing of the Constitution and divide them between the federal government and the regions.

This article asks whether such specificity is desirable in the long run and raises questions of whether the Constitution can withstand major economic changes with ramifications upon the income tax system. The article, for example, asks whether the Ethiopian Constitution is broadly consistent with the normative theories of fiscal federalism, and if not, what the possible implications are going to be. For that, this article starts with a brief overview of the normative theory of fiscal federalism. Then, the article deals with the income tax assignment approach of the Ethiopian Constitution and forwards some theories about its inspiration - the scheduler orientation of Ethiopian tax being one of them. It also deals briefly with the practice of income tax law making (both at the federal level and the regions) and what that means or says about federal-state fiscal relations in Ethiopia. The major theme of this article will be the implications or concerns of revenue assignment under the Ethiopian Constitution from an income tax point of view. And finally, the article ends with some concluding remarks.

\section{Theories of Fiscal Federalism In Income Tax Assignment}

Few countries pursue the course of decentralization on grounds of its perceived economic efficiency or equity. Political, social, cultural or historical forces are likely to dominate the discourse of decentralization at the formative stage of its evolution and development. ${ }^{3}$ Nonetheless, some economists have sought to justify decentralization on economic grounds. One advantage of decentralization is that it accommodates diverse needs and preferences of citizens. Since the benefit incidence of certain public goods is spatially limited, decentralization permits provision of these goods consistent with the various preferences of persons and communities. ${ }^{4}$ Related to this, it is argued that individuals attain greater freedom and responsibility when public goods are provided in a

${ }^{3}$ Richard A. Musgrave and Peggy B. Musgrave (1989, $5^{\text {th }}$ edition), Public Finance in Theory and Practice (New. York: McGraw Hill), p. 446.

${ }^{4}$ Ibid, p. 456; see also John F. Due and Ann F. Friedlaender (2002), Government Finance: Economics of the Public Sector (Delhi: A.I.T.B.S. Publishers \& Distributors), p. 486. 
decentralized fashion. ${ }^{5}$ Besides, decentralized decision-making approximates those of the market more closely than those of centralized provision because it allows for closer popular control over the provision of public goods. ${ }^{6}$ And lastly, economists believe that decentralization encourages experimentation and innovation in the provision of public goods. ${ }^{7}$

The normative theories of fiscal federalism start from the premise that tax powers (besides being a means of generating revenues for government) are also instruments of expenditure powers. Hence, a logical point to start is to identify the expenditure powers of the federal government vis-à-vis the states, and to allocate taxes that are instruments of these powers to the layer or level of government possessing those expenditure powers. ${ }^{8}$ That is why assignment of expenditure powers should precede the assignment of tax powers, for otherwise there is a danger of misallocation of tax powers to a layer that is not invested with corresponding expenditure powers.

In the realm of expenditure assignment, economists use the classification of the economic functions of a state first developed by Richard Musgrave, which views the role of a state as one of 'allocation', 'distribution' and 'stabilization'. Without inviting much distraction from the main points, it may be in order to define 'allocation', 'distribution' and 'stabilization' functions. Richard and Peggy Musgrave describe the allocation function as 'the process by which total resource use is divided between private and social goods and by which the mix of social goods is chosen' ${ }^{10}$ Social goods (popularly known as public goods) are those goods which exhibit certain characteristics for which the market mechanism is unsuitable. ${ }^{11}$ National defense is a classic example of these goods.

The distribution function of fiscal policy calls for adjustment of the distribution of income and wealth in conformity with what society regards fair or just state of distribution. Here taxation may enter the process as an instrument

${ }^{5}$ Bernard P. Herber (2005, $5^{\text {th }}$ edition), Modern Public Finance (Delhi: A.I.T.B.S. Publishers \& Distributors), p. 338

${ }_{7}^{6}$ Ibid, p. 337; Due and Friedlaender, supra note 4, p.487.

${ }^{7}$ Due and Friedlaender, supra note 4, at 487; there are of course downsides to decentralization, such as loss of scale economies and destructive tax competition; see Vito Tanzi (2001), On Fiscal Federalism: Issues to Worry About at

$<$ http://www.imf.org/external/pubs/ft/seminar/2000/fiscal/tanzi.pdf $>$; Herber, supra note 5, pp. 335-337.

${ }^{8}$ See Anwar Shah (2007), "Introduction: Principles of Fiscal Federalism”, in Anwar Shah (ed.), The Practice of Fiscal Federalism: Comparative Perspectives, A Global Dialogue on Federalism, vol. 4, (McGill: Queen's University Press), p. 9.

${ }^{9}$ See Richard and Peggy Musgrave, supra note 3, pp.3-14.

${ }^{10}$ Ibid, p. 6.

${ }^{11}$ Ibid, p. 7. 
of transfer of income and wealth from the high income to low income households. ${ }^{12}$ And stabilization function has the objective of maintaining high employment, reasonable degree of price level stability (in other words, fighting inflation) and an appropriate level of economic growth. ${ }^{13}$ Again taxes enter the picture as fiscal instruments to achieve any or all of the above objectives. ${ }^{14}$ There are disagreements among economists and politicians over how much (and sometimes if) governments are in a position to deal with these issues. Once the issues are settled, however, taxation is definitely one of the most prominent instruments for achieving these economic and political objectives.

Economists generally believe that the allocation function of the public sector is subject to wider decentralization to lower levels of government while the other two (distribution and stabilization) functions are beneficially reserved to the central/federal government. ${ }^{15}$ In the division of allocation functions of government, one principle that is frequently invoked is the 'subsidiarity principle', which supports assignment to the lowest order of government (or the government closest to the people) unless there are compelling arguments for assignment to the higher orders of government. ${ }^{16}$ The principle of 'subsidiarity' is also supported on grounds of efficiency. Efficiency demands that the jurisdiction that has control over the minimum geographic area capable of internalizing the benefits as well as costs should be charged with the responsibility of providing the service. ${ }^{17}$ Local and state governments are the primary candidates for the provision of most public goods on grounds of efficiency. Local and state governments understand the concern of local residents better; they are more responsive to the people for whom the services are intended; and unnecessary layers of jurisdiction (in other words bureaucracies) are eliminated and competition and innovations are enhanced when local and regional jurisdictions assume the provision of public goods. ${ }^{18}$ Only public goods for which compelling cases can made for national provision should be retained by the federal government. The compelling grounds are the existence of substantial externalities or economies of scale and countervailing

${ }^{12}$ The distribution function may be achieved through progressive taxes combined with subsidies of low income households or financing of public services catering primarily for low income households (e.g. subsidized low income housing), see Richard and Peggy Musgrave supra note 3, pp.6 and 11.

${ }^{13}$ Ibid, p. 6.

${ }_{15}^{14}$ Ibid, p. 13 .

15 Ibid, p. 455. See also, Charles M. Tiebout (1956), "A Pure Theory of Local Expenditures", the Journal of Political Economy, Vol. 64, No. 5, at 418.

${ }^{16}$ Anwar Shah, supra note 8, p. 8.

${ }^{17}$ Ibid, p. 9.

${ }^{18}$ Ibid. 
administrative and compliance costs. ${ }^{19}$ With the exception of national public goods like national defense, many other public services can be decentralized to the states and local governments.

The literature on fiscal federalism has a contrary advice with respect to the assignment of both distribution and stabilization functions. The reason in both cases is the fear of leakage that might result from disparate regional and/or local policies of distribution and stabilization. ${ }^{20}$ In the area of distribution, for example, no regional or local government could be effective in its distributive goals if other regions move in an opposite direction. ${ }^{21}$ Similarly, no regional and/or local government can be effective in stabilizing its economy when its efforts can be readily undermined through leakage resulting from the contradictory activities of other regions or localities.

The theories of fiscal federalism in the areas of revenue assignment are not of peremptory nature. Federal systems will do well to heed these normative theories, but departures from them are tolerated, and indeed many federal systems do not strictly adhere to these theories. That is why we observe divergent approaches of revenue assignment in different federal systems, which goes to show that fiscal federalism is not just about economics. In any case, based largely on the expenditure assignments in federal systems, the normative theories of fiscal federalism suggest the following criteria in the assignment of revenue powers: ${ }^{22}$

(i) progressive redistributive taxes should be central;

(ii) taxes suitable for economic stabilization should be central; lower level taxes should be cyclically stable;

(iii) tax bases distributed highly unequally between jurisdictions (e.g., resource taxes) should be centralized; taxes on mobile factors of production are best administered at the center;

(iv) taxes based on residence (e.g., sales of consumption goods to consumers or excises) are suited for states;

(v) taxes on immobile factors (e.g., property taxes) are better left for local levels;

(vi) benefit taxes and user charges might be used at all levels.

${ }^{19}$ Ibid, p. 10.

${ }^{20}$ Richard and Peggy Musgrave, supra note3, pp. 454-455; Due and Friedlaender, supra note 4 , p. 486.

${ }^{21}$ For contrary arguments, see Anwar Shah, supra note 8, pp. 11-13.

${ }^{22}$ Kibre Moges (1994), 'The Conceptual Framework for Fiscal Decentralization', in Eshetu Chole (ed.), supra note 1, pp 5-6 quoting Anwar Shah, Perspectives in the Design of Intergovernmental Fiscal Relations (1991), WPS, World Bank. 
The following table shows the broad distribution of taxes if the theory of fiscal federalism were to hold sway:

Table 1: Tax Assignment according to the theory of Fiscal Federalism

\begin{tabular}{|l|l|l|l|}
\hline Tax Category & \multicolumn{2}{|c|}{ Determination of } & \multicolumn{1}{|c|}{$\begin{array}{c}\text { Tax Collection } \\
\text { and } \\
\text { Administration }\end{array}$} \\
\hline & Base & Rate & \\
\hline Customs duties & F & F & F \\
\hline Income Tax & F & F, S & F \\
\hline Estate \& Gifts & F & F, S & F \\
\hline Corporate Income Taxes & F & F, S & F \\
\hline Resource Taxes & F & F, S & F \\
\hline Retail Sales & S & S & S \\
\hline VAT & F & F, S & F \\
\hline Excises & S & S & S \\
\hline Property tax & S & L & L \\
\hline User charges & F, S, L & F, S, L & F, S, L \\
\hline
\end{tabular}

Source: Kibre Moges ${ }^{23}$ Table 2, quoting Shah $^{24}$

Notes: $\mathrm{F}=$ Federal $\quad \mathrm{S}=$ State $\quad \mathrm{L}=$ Local

\section{Assignment of Income Tax Powers: The Impact of the Schedular System on the Constitution}

Federal systems do not exhibit any pattern of uniformity in allocating income taxes. $^{25}$ Although not conclusive, there appears to be some differences in approaches between those federal systems that have a global system of income taxation and those that have adopted schedular approaches of income taxation. ${ }^{26}$

${ }^{23}$ See Ibid, p. 6 .

${ }^{24}$ Anwar Shah, supra note 22.

${ }^{25}$ Solomon Negussie (2006), Fiscal Federalism in Ethiopian Ethnic-Based Federal System (Netherlands: Wolf Legal Publishers), p. 127.

${ }^{26}$ The schedular approach of income taxation, still in use in some countries including Ethiopia, segments income by sources. Each schedule of the income tax has its own rules of computation of gross income, taxable income, tax rates, and methods of 
Countries with global system of income taxation tend to allocate income taxes to the federal government while those with schedular system of income taxation tend to share income taxes between the federal government and states. ${ }^{27}$ The Ethiopian Constitution of 1995 seems to follow a set formula in allocating income tax powers between the federal government and the regional governments. With respect to employment income taxes (i.e., taxes on wages and emoluments), ${ }^{28}$ the Constitution allocates them on the basis of the identity of the employer. If the employer is the federal government or an international organization, the federal government exercises an exclusive power of taxation of employment income. ${ }^{29}$ If an employer is anyone other than these two (that includes regional governments, private enterprises and non-governmental organizations), the power to impose tax on employment income belongs to the regional governments. ${ }^{30}$ Incidentally, some have argued that employment income taxes are assigned to the regional governments on grounds of the benefits employees receive from regional governments. ${ }^{31}$ If employment

assessment. In contrast global income tax systems aggregate the income of a person from 'all' sources and apply the tax rate on the whole. In reality, there are no pure global systems of income taxation. Some types of income (e.g. capital gains) may receive special treatment in an otherwise global income tax system; see John Tiley (2005, $5^{\text {th }}$. ed.), Revenue Law, Hart Publishing, p. 136; see also Lee Burns and Richard Krever, Individual Income Tax, in Victor Thuronyi (1998, ed.), Tax Law Design and Drafting, International Monetary Fund, Vol. 2, pp,. 495-496.

As Holmes noted:

"[u]nder the global system of income taxation, all income, regardless of its source is aggregated and subjected to a single schedule. The purpose of the global approach is 'to distribute interpersonal tax burdens, vertically and horizontally, according to the ability to pay principle'. Aggregating income under a global tax renders a progressive tax scale more effective (vertical equity) and does not discriminate between income from different sources (horizontal equity). Taxation under the schedular system identifies income by source and imposes tax, sometimes at different rates, separately on the total income derived in each source clarification." Kevin Holmes (2001), The Concept of Income: A Multidisciplinary Analysis (The Netherlands: IBFD Publications), p. 28.

${ }^{27}$ Solomon Nigussie, supra note 25, p. 127.

${ }^{28}$ Employment income taxes are sometimes mistakenly referred to as 'personal income taxes' in Ethiopia. There are no personal income taxes in Ethiopia, in the strictest sense of the expression.

${ }^{29}$ The Constitution of the Federal Democratic Republic of Ethiopia, Federal Negarit Gazetta, $1^{\text {st }}$ Year, No. 1, Article 96(2); Solomon Nigussie, supra note 25, p. 127.

${ }^{30}$ Constitution, supra note 29, Article 97(1).

${ }^{31}$ Solomon, for example, writes that the allocation of personal income taxes to the regional governments is justified because these taxes, according to him, finance local public goods and services; see Solomon Nigussie, supra note 25, p. 128. 
income taxes are cast as 'benefit taxes', it may be justified to assign these taxes to the regional governments, but that is not the reason. ${ }^{32}$ Employment income taxes are assigned on the basis of the identity of the employers, rather than the residence of the employees. It is difficult to see how the benefits employees receive can be gleaned from the identity of the employers. If benefits were the reason why employees are subject to regional tax powers, employees of the federal government and international organizations working and residing in the regions should also also pay these taxes to the respective regional governments of which they are residents.

The formulaic allocation of income taxes extends to other sources of income subject to tax in Ethiopia. Income tax on business profits is allocated on the basis of ownership of the business or the legal form of business organization. The federal government is given exclusive power of taxation of profits generated by government enterprises owned by the federal government. ${ }^{33}$ The regional governments hold exclusive power of taxation over government enterprises owned by the regional governments and private sole-proprietorship businesses. ${ }^{34}$ The regional governments also hold an exclusive power of taxation of income from agricultural activities, as long as the income is derived by private farmers and cooperative societies. ${ }^{35}$ The Constitution assigns taxation of corporate income as well as income of shareholders concurrently to the federal government and the regional governments. ${ }^{36}$

The other source of income tax which undergoes a similar formula of 'slicing the pie' is rental income tax. This source of income is divided by the Constitution between the federal government and regional governments based

${ }^{32}$ See Richard and Peggy Musgrave, supra note 3, p. 454. The distinction between benefit-based taxes and general purpose taxes is a matter of degree rather than of substance. In principle, all taxes must be based on the benefits derived from public services. But specific benefits need not be (and in some cases cannot be) proved for taxes to become general obligations on individual taxpayers. Unlike in the general purpose taxes, however, there is a strong link between the taxes and the benefits taxpayers receive in the case of benefit-based taxes. Excise taxes on petroleum, for example, are justified by the benefits road users derive from the construction and maintenance of roads. These taxes are not general purpose taxes. Their burdens fall on road users only. Similarly, income taxes may be used particularly at the local government level to impose the burden of local government services on residents of the locality only. Residence becomes an indirect identifier of the beneficiaries of local government services.

${ }^{33}$ These are profit-making enterprises; Constitution, supra note 29, Article 96(3).

${ }^{34}$ Ibid, Article 97(4) \& (7).

${ }^{35}$ Ibid, Article 97(3).

${ }^{36}$ Ibid, Article 98(2). 
on the identity of the 'lessor' or 'landlord'. If the lessor is the federal government (in other words, if the federal government owns the building leased), the Federal Government has an exclusive power of taxation over that source of income. ${ }^{37}$ The power to impose tax on rental income derived from any other property (this includes all regional government owned properties and privately-owned properties) is exclusively given to the regional governments. ${ }^{38}$

As can be readily observed, the Ethiopian Constitution goes to great lengths in listing the tax powers of both the federal government and the regional governments in a language as concrete as can be imagined. But if Article 99 were any evidence, there was no intention to exhaust all the tax powers, much less the income tax powers. Those taxes which are not expressly stated in Articles 96, 97 and 98 are regarded as 'undesignated' and should undergo allocation by the $2 / 3$ rds majority vote of the two Houses. ${ }^{39}$ In providing for this special procedure to settle the locus of 'undesignated taxes', the Constitution departs form the principle of 'residuality', which is followed in the area of expenditure assignment. ${ }^{40}$

It is now more than fifteen years since the Constitution was approved. Since the approval of the Constitution in 1995, the Joint Houses met and voted to allocate certain income taxes which were undesignated by the Constitution. ${ }^{41}$ The Joint Houses designated income taxes on royalties derived by enterprises as 'concurrent' taxes and royalties derived by individuals as 'regional' taxes. ${ }^{42}$ There are still many more undesignated and yet to be discovered income tax sources awaiting determination of the two Houses. ${ }^{43}$

In thinking about the Ethiopian Constitution, we may wonder as to what could have motivated the framers of the Constitution to divide income tax powers (indeed all tax powers) in such a particular and specific manner. In attempting answers to this question, we may postulate four different hypotheses:

${ }^{37}$ Ibid, Article 96(6).

${ }^{38}$ Ibid, Article 97(6).

${ }^{39}$ Ibid, Article 99.

${ }^{40}$ Ibid, Article 52(1).

${ }^{41}$ Berhanu Assefa (2006). Undesignated Powers of Taxation in the Distribution of Fiscal Powers between the Central and State Governments under the FDRE Constitution, LL.B Thesis, Faculty of Law Library, Archives, pp. 59-60.

${ }^{42}$ Ibid.

43 Capital gains taxes (although stated as taxable in the Federal Income Tax Proclamation) are arguably undesignated taxes; see Income Tax Proclamation No. 286/2002, Federal Negarit Gazetta, $8^{\text {th }}$ year, No. 34, Article 37; There are also many other types of income not even anticipated under the current income tax laws of Ethiopia - annuities are a good example. 
(i) The general normative theories of fiscal federalism as developed mainly by economists;

(ii) The comparative experience of other federal systems;

(iii) The division of revenues during the Transition Period (1992-1995); or

(iv) The schedular feature of Ethiopian income tax system on the ground.

We may dismiss the first hypothesis (the normative theory of fiscal federalism) as the most improbable, for we quickly notice what little resemblance there is between what the normative theory prescribes and how the Ethiopian constitution divides tax powers. The normative theories of fiscal federalism generally favor assignment of income taxes to the federal government, which is clearly not the case for the Ethiopian Constitution. Besides the normative theories of fiscal federalism seldom get into as many details as the Ethiopian Constitution does. It is unlikely that the framers had the normative theories of fiscal federalism in mind in writing the revenue provisions of the Constitution.

Comparative experience also has little influence over the revenue provisions of the Ethiopian Constitution except perhaps in shaping the provisions of the law that preceded the Ethiopian Constitution - Proclamation No. 33/1992- in regulating division of revenues in the Ethiopian federal system. The details of the Ethiopian Constitution in this regard are almost unprecedented. No Constitution to my knowledge goes to as much detail as the Ethiopian Constitution in allocating tax powers between the two layers of the federation. The Indian Constitution is fairly detailed on matters of tax power sharing, but not even the Indian Constitution comes close to the Ethiopian Constitution. $^{44}$

That leaves us with the two hypotheses left. There is reason to believe that the 1992 law and the schedular design of the Ethiopian income tax system had something to do with shaping the revenue provisions of the Ethiopian Constitution. The 1992 law regulated the division of revenues during the Transition Period and the political forces that dominated during the transition period were also the forces that shaped the writing of the Constitution. A cursory comparison of the 1992 law with the Constitution's revenue provisions cannot pass without noticing the striking resemblance between the two laws. To be sure, there are minor differences of language, but their similarity is striking overall. The categories of revenues are similar; the types of taxes that are

${ }^{44}$ We may consult the Constitutions of the Swiss, Canadian, Australian, Nigerian, and Indian Constitutions. None of them are as detailed as the Ethiopian Constitution. The US Constitution does not even bear comparison; see Constitutions of the World at $<$ http://www.constitution.org/cons/natlcons.htm> last visited on December 6, 2009. 
categorized as federal, state or concurrent are also similar. ${ }^{45}$ The details are also strikingly similar, if not downright identical. There is one area where the 1992 law clearly had an upper hand over the Constitution - it has more rules about revenue sharing than does the Constitution, obviously because the 1992 law dealt with revenue sharing and revenue sharing only, whereas the Constitution, like any constitution, deals with many matters other than just revenue sharing.

The 1992 law is abrogated by the Constitution, but it has thrown many a light over matters that were left unsaid or said ambiguously by the Constitution (although this is not publicly acknowledged). For instance, the Constitution says nothing about the levying and collection of concurrent taxes but the 1992 law has a clear provision on this which states that concurrent taxes are fixed and collected by the central (federal) government and then shared with the regions on the basis of derivation. ${ }^{46}$ When the Joint Houses determined the formula of sharing revenues from concurrent sources, their decision went the way of the procedures laid down in the 1992 law. This is more than mere coincidence. The 1992 law is the voice behind the silences and ambiguities of the 1995 Constitution.

We may trace the Constitution's revenue provisions to the 1992 law, but to what do we trace the 1992 law itself? This takes us to the design of the income tax system of Ethiopia - the fourth hypothesis. In reading the revenue provisions of the Constitution, one cannot but be struck by the conservative approach of the framers of the Constitution. We quickly realize that they did not set out to 'reinvent the wheel' but to allocate existing taxes on the basis of simple indicators like the identity of employers, lessors or the form of business organizations. It is instructive to note that neither the 1992 law nor the 1995 Constitution occasioned a reform of the tax system to bring into conformity with the division of revenues, because both laws required division of existing taxes rather than reorganizing the tax system on the ground. No major income tax reform occurred until seven years after the Constitution, and the major income tax reforms of 2002 do not seem to have been motivated by the Constitution but by factors that had little to do with the federal arrangement.

It is difficult to imagine the division of revenues like that of the Ethiopian Constitution without the schedular income tax system on the ground. Since the revenue provisions divide revenues from existing taxes, they were more specific and more particular than the schedules of the income tax - that could not have

45 Compare Article 96 of the Constitution with Article 5(2) of Proclamation No. 33/1992; Article 97 of the Constitution with Art. 5(3) of Proclamation No. 33/1992; and Art. 98 of the Constitution with Article 5(4) of Proclamation No. 33/1992, supra notes 2 and 29.

${ }^{46}$ See supra note 2, Article 8(4). 
been avoided unless the sharing was based strictly on the existing schedules. If we scrutinize the revenue provisions of the Constitution closely, we realize that these provisions make reference to the existing income tax sources like employment, business, lease and agriculture to allocate tax powers over those to either or both layers of the federation. We can assign schedules to each of these sources mentioned in the Constitution or trace them to some of the autonomous income tax laws of Ethiopia, like the agricultural income tax laws and the mining income tax law. Those who worked out the assignment formulas of the Constitution most likely had a copy of the existing taxes of Ethiopia at the time and simply decided to allocate the taxes on criteria that seemed to them could be executed without a hitch on the ground.

\section{Income Tax Lawmaking in Practice}

For many years after the passing of the Constitution, the regional governments simply used the federal tax laws as source of authority to levy and collect regional taxes, including income taxes. ${ }^{47}$ The turnover tax law, for example, is a federal tax law, but the tax is collected mostly by the regional governments. Some have wondered if this practice had any constitutional basis, but since taxpayers mounted no challenge, the practice has so far attracted little attention. $^{48}$

The one area of taxation powers where the regional governments have shown some legislative muscle is in the agricultural income taxes, presumably because these taxes are the exclusive preserve of the regions. ${ }^{49}$ In recent times, however, some regional governments have managed to pass their own income

47 Timothy R. Muzondo et al (2000), "Ethiopia: Introduction of a VAT and a Presumptive Income Tax and Reform of the Income Tax", International Monetary Fund, Fiscal Affairs Department, p.21.

${ }^{48} \mathrm{Ibid}$; the challenge would have spurred the regional governments to issue their own tax law, which was very easy to do. An otherwise savvy taxpayer might frown upon such practice but decide against challenging it because he knew that the regions could produce their own tax laws upon instant notice.

49 There is even some variation among regions in the taxation of agricultural income. In some regions (Oromia, Benishangul-Gumuz and Gambella) the tax is levied on agricultural income with a progressive tax rate scale, while in other regions, the tax is a fixed amount per hectare of land; see The Federal Democratic Republic of Ethiopia (May 2007), the New Federal Budget Grant Distribution Formula, House of Federation, Economic and Social Study Department, Addis Ababa, pp. 20-21. Some say that this variation is superficial, arguing that the diktat comes from the center even in the area of agricultural income taxes; see Deso Chemeda (2008), Agricultural Income Taxation in Oromia, Senior Thesis, Faculty of Law, Addis Ababa University (unpublished). 
tax laws - probably upon realizing that they could no longer invoke federal tax laws to levy and collect regional income taxes. ${ }^{50}$

However, before we find fault with the practice of tax law-making in the regions, we must remember that the Federal tax law making process is not entirely innocent. When the Federal Government issued the current income tax law in 2002, it was barely aware of the niceties of the federal system - if the content of the 2002 income tax law is anything to go by. The 2002 income tax law covers not just federal income tax bases, but also state tax bases, and undesignated tax bases. The best illustration of this tax law's overreach is to compare the 2002 income tax law with the income tax laws of Ethiopia back in the days when Ethiopia was a unitary state. ${ }^{51}$ There is surprisingly no difference between the two tax regimes in terms of income tax bases upon which tax was to be levied.

Another way is to compare the tax bases mentioned as subject to income tax under the 2002 tax law with the tax bases that are assigned exclusively to the regional governments and those that were 'undesignated' in the Constitution. Of the tax bases given to regional states under the Constitution, we may mention taxation of small businesses (called category $\mathrm{C}$ taxpayers). These taxpayers are subjects of regional state jurisdiction (unless they are organized as companies) by virtue of Article 97(4) of the Constitution. ${ }^{52}$ The income tax law of 2002 has detailed provisions on the assessment of the income and taxation thereof of small businesses. A presumptive assessment method (known as 'standard assessment') has been instituted for small businesses, with standard assessment tables for all types of small businesses attached to the 2002 income tax law. ${ }^{53}$

Of the undesignated taxes (at least undesignated in 2002), we may cite examples of taxes on royalties from patents and copyrights, taxes on interest accruing on bank deposits, and tax on transfer of capital. ${ }^{54}$ Since the 2002

${ }^{50}$ See, for example, Oromia Regional Government Income Tax Proclamation No. 74/2003, Megeleta Oromia; Amhara Regional Government Income Tax Proclamation No. 76/2003, Zikra Hig.

51 Compare the Income Tax Proclamation No. 286/2002 with the now repealed Proclamation No. 173/1961 (as amended).

${ }^{52}$ Article 97(4) of the Constitution in part states: "States shall levy and collect profit... taxes on individual traders carrying out a business within their own territory.' See, Constitution, supra note 29.

53 See Income Tax Proclamation, supra note 43, Article 66; Council of Ministers Income Tax Regulations No. 78/2002, Federal Negarit Gazetta, $9^{\text {th }}$ year, No. 18, Articles 21 and 22.

${ }^{54}$ See Income Tax Proclamation No. 286/2002, supra note 43, Articles 31, 36 and 37; Some of these taxes have since 2002 been designated by the Joint Houses (see above); Berhanu Assefa, Supra note 41. 
income tax law came out with little consciousness of the federal structure and division of powers, the regions simply relied upon this ostensibly federal tax law to levy and collect regional income taxes. ${ }^{55}$ It is only later that some of the regions even moved to issue their own tax laws. But the regions did not really issue their own tax laws if by issuing tax laws one implies a self-conscious, selfdirected, deliberate process of law making. All of the regions that have issued their own laws have taken the federal tax law of 2002 as a model.. ${ }^{56}$ The regional income tax laws are not just eerily similar to the federal tax law; the regions have not even bothered to sift out provisions that are clearly inappropriate from the vantage of regional income tax jurisdiction. For example, we find the same article (number as well as content) referring to a provision that is clearly not a regional income tax jurisdiction -dividend tax. ${ }^{57}$

\section{Possible Problems and Challenges Ahead}

A federal system of government by definition involves decision-making at multiple levels of government. While this decision-making process is more amenable to participatory government and rigorous procedures to reach a consensus, it can lead to gridlocks if different levels of government entertain divergent positions on reform in one or another direction. ${ }^{58}$ Divergent positions are to be expected from time to time between the federal government and the states. In contrast, in unitary governments, since decision-making at least in theory is made by the center and local governments have little autonomy of their own, we can expect reforms to go through more quickly than in federal systems. ${ }^{59}$

One possible problem that might arise from the assignment formula adopted in the Ethiopian Constitution is in the prospect of transforming the income tax system of Ethiopia. Suppose the federal government is convinced that the

${ }^{55}$ In defense of the federal government, some may argue that the Federal Government has the duty to nurse a nascent federal system by writing a 'common tax legislation,' from which the regional governments may take what they want. But the Federal Government could have followed less paternalistic approaches to assist the regional governments in this regard: like writing a non-binding model regional tax law.

${ }^{56}$ Even the preamble of the federal income tax law is used verbatim.

${ }^{57}$ See Article 34 of both Oromia Regional State and Amhara Regional State Income Tax Proclamations, supra note 50, and compare them with Article 34 of the Federal Income Tax Proclamation, supra note 43.

${ }^{58}$ See Jessica R. Adolino and Charles H. Blake (2001), Comparing Public Policies, Issues and Choices in Six Industrialized Countries (Washington, DC: CQ Press), pp. 66-68.

${ }^{59}$ Ibid, p. 66. 
income tax system should be global. ${ }^{60}$ Because of the modality of assignment adopted in the Ethiopian Constitution, this type of reform will require not just reforming the tax system at the federal level but also the income tax systems of the regional governments. The federal government alone cannot succeed in transforming the income tax system from one that is schedular to a global income tax system. It requires the consent of all regions, which is usually difficult to obtain, if the regions exercise substantial autonomy in judgment. The only course of action open to the federal government is to seek constitutional amendment to push through that sort of tax reform. What would it take for a constitutional amendment to succeed, whatever is on the table? A constitutional amendment of this kind requires a $2 / 3$ rds majority vote in favor of the proposal by the joint Houses of Peoples' Representatives and of the Federation and a vote by a majority in favor of the proposal by $2 / 3 \mathrm{rds}$ of the regional councils. ${ }^{61}$ Each of these requirements is a tremendous hurdle. We must remember that not all proposals for constitutional amendment are equal. Some amendments are so procedural and formal that they are guaranteed to slide through the hurdles very easily. Others are so radical that their chances of getting through these hurdles are very slim. Tax reform, particularly the one sought above, is of the latter type.

We must anticipate a great deal of resistance from the regional governments in particular. If the tax system were to become global, what would happen to regional tax powers? Would the tax reform lead to erosion and weakening of regional tax sources? These are some of the fears the regional governments would express and take actions to forestall. The fear that the tax reform might lead to the federal government taking over the tax powers reserved to the regions is enough to decide the results against the proposal. The regions wield substantial power over the course of constitutional amendments and they are going to use them if they perceive that the amendment (even if a minor one) affects their vested interests. As a result, many a sound proposal will be stymied for lack of support or enthusiasm for it at the regional level.

In rejoinder to this fear, the 2002 tax reforms may be held up as evidence that reform was possible after all. Seven years after the passing of the Constitution, the Federal Government of Ethiopia successfully carried out a major income tax reform without having to go through the rigmaroles of constitutional amendments. The 2002 tax reforms introduced what might be

${ }^{60}$ For a brief distinction between schedular and global income tax systems, see foot note 26 above.

${ }^{61}$ See Constitution, supra note 29, Article 105(2). 
called 'major' changes in the income tax system of Ethiopia. ${ }^{62}$ If tax reform of that magnitude succeeded seven years after the Constitution, we may ask, why not in the future?

We must realize that the 2002 tax reforms occurred in an extremely auspicious political environment. They occurred at a time when both the federal government and the regional governments were controlled by a single party. ${ }^{63}$ The ruling party is known for enforcing strict party discipline on its member organizations as well as affiliates. ${ }^{64}$ The delicate balance of 'enforced consensus' is held together for the moment by the ruling party's system of party discipline. If and when opposition groups take control of either the federal bodies or one or two of the regions, the balance may not hold. If that happens through constitutional means (i.e., through free and fair elections), fierce battles will be fought over any serious proposal for an amendment of the Constitution without which a tax reform of any magnitude is unlikely to succeed.

The other challenge and concern surrounding the division of revenues under the Ethiopian Constitution is whether it leaves the Federal Government with sufficient fiscal powers to achieve desirable fiscal policies of stabilization and distribution (For comparison of the assignment of revenues under the theories of fiscal federalism and under the Ethiopian Constitution, see Table 2 below). Taxation is an important instrument of fiscal policy, and if the latter were to become effective, the federal government should wield sufficient powers of taxation to achieve desirable economic policies. ${ }^{65}$ The extent to which any government can effect desirable changes in tax rates and bases depends upon that government's control over tax rates and tax bases for the purposes of implementing its fiscal policy as well distribution of income and wealth. ${ }^{66}$

${ }^{62}$ The 2002 income tax reforms did not transform the income tax system of Ethiopia from a schedular one to a global system; but there were many other areas where major changes were introduced.

${ }^{63}$ Suberu writes "not only does (sic) the EPRDF coalition and its affiliated parties control all governments at the federal and regional state levels by relatively large majorities, but the national leadership appears to have foisted a highly disciplined and intrusive central party structure on the whole federal administration system", Rotimi Suberu, (2006), 'Federalism and the Management of Ethnic Conflict: the Nigerian Experience', in Turton, David, supra note 1 p. 85.

${ }_{65}^{64}$ See Assefa Fiseha, supra note 1, pp. 156-158.

${ }^{65}$ Girma Seyoum, 'Fiscal Decentralization and Macroeconomic Management in Ethiopia', in Eshetu Chole, supra note 1, at 135; Richard and Peggy Musgrave, supra note 3, pp. 11, 13; see also, John Kenneth Galbraith $\left(7^{\text {th }}\right.$ printing, 1958), the Affluent Society (A Mentor Book), p. 247.

${ }^{66}$ Girma Seyoum, in Eshetu Chole, supra note 1, p. 135; Richard and Peggy Musgrave, supra note 3, pp. 11, 13. 
Table 2: Comparison of Tax Assignment under the Ethiopian Constitution and the Theory of Fiscal Federalism

\begin{tabular}{|l|c|c|c|}
\hline \multicolumn{1}{|c|}{ Type of tax } & $\begin{array}{l}\text { Ethiopian } \\
\text { Constitution }\end{array}$ & $\begin{array}{l}\text { Fiscal Federalist } \\
\text { Theory }\end{array}$ & Article \\
\hline $\begin{array}{l}\text { Income tax on Federal } \\
\text { Government and International } \\
\text { organization employees }\end{array}$ & Federal & Federal/state & $96(2)$ \\
\hline $\begin{array}{l}\text { Income tax on federal } \\
\text { government enterprises }\end{array}$ & Federal & Federal & $96(3)$ \\
\hline $\begin{array}{l}\text { Income tax on lottery winnings } \\
\text { and other games }\end{array}$ & Federal & State & $96(4)$ \\
\hline $\begin{array}{l}\text { Income tax on air, rail and sea } \\
\text { transport services }\end{array}$ & Federal & Federal & $96(5)$ \\
\hline $\begin{array}{l}\text { Income tax on federally owned } \\
\text { houses }\end{array}$ & Federal & Federal & $96(6)$ \\
\hline Taxes on monopolies & Federal & Federal & $96(8)$ \\
\hline $\begin{array}{l}\text { Income tax on state government } \\
\text { employees and employees of } \\
\text { private enterprises }\end{array}$ & State & Federal/state & $97(1)$ \\
\hline $\begin{array}{l}\text { Income tax on private farmers and } \\
\text { agricultural cooperatives }\end{array}$ & State & Federal/state & $97(3)$ \\
\hline $\begin{array}{l}\text { Income tax on individual traders } \\
\text { services }\end{array}$ & State & Federal/state & $97(4)$ \\
\hline $\begin{array}{l}\text { Income tax on rental of private } \\
\text { houses and other properties }\end{array}$ & State & Federal/state & $97(5)$ \\
\hline $\begin{array}{l}\text { Income tax on state government } \\
\text { owned enterprises }\end{array}$ & Federal/state & $97(6)$ \\
\hline $\begin{array}{l}\text { Income tax on employees of state } \\
\text { government owned enterprises } \\
\text { shareholders }\end{array}$ & Federal/state & $97(7)$ \\
\hline concurrent) & $\begin{array}{l}\text { Federal/state } \\
\text { (concurrent) }\end{array}$ & $98(2)$ \\
\hline
\end{tabular}

Source: Ethiopian Constitution 1995), supra note 29, and Kibre Moges, in Eshetu Chole, supra note 1, p. 6. 
The division of revenues adopted in the Constitution is not conducive to the attainment of optimal stabilization and distribution policy by the federal government. In the assignment of expenditure powers, the Ethiopian Constitution is broadly consistent with the theories of fiscal federalism - at least in the assignment of stabilization and redistribution powers. ${ }^{67}$ In the assignment of tax powers, however, it did not seem like this was taken into account- which may raise fears of countercyclical policies at the regional level. The Constitution may have followed some simple indicators for division of revenues between the two layers of Ethiopian federation, but in so doing it may have opened itself to some problems.

Let's take some examples to illustrate our point. Assume that the Ethiopian economy has experienced a rise in prices, raising fears of inflation. In that situation, the theory recommends that the federal government should raise tax rates to reduce aggregate demand. ${ }^{68}$ This kind of policy can be effective only if the federal government has the constitutional power to raise tax rates that affect all households and businesses, at least a substantial number of households and business to have traction. Under the current division of revenue powers, there are many households and businesses outside federal control. In the area of income taxes, the federal government has no control over employees of regional governments and private enterprises, the profits of sole proprietor businesses (whose size and number can only increase in the future) and more importantly, farmers. What if the regions were reluctant to go along with the ideas of raising taxes?

The same fears can be expressed over the capacity of the federal government to implement appropriate distribution policy, if need be through the instrumentality of taxes. There is a large swath of taxpayers out there who are not subject to federal tax powers. Can the federal government be effective in its distribution policies when these taxpayers are not directly affected by its tax policies? Can the federal government impose progressive income taxes with a view to redistributing income and wealth? It is doubtful.

Many federal systems permit income taxation at both layers of government (federal and state). ${ }^{69}$ So one may ask: why is Ethiopian revenue assignment a source of problem when others are not? The issue is not really about devolution of income taxes to the regions but the peculiar approach taken by the Ethiopian Constitution. In other federal systems, the federal government retains the

${ }^{67}$ See Constitution, supra note 29, Article 51(2), (4), \& (7).

${ }^{68}$ Richard and Peggy Musgrave, supra note 3, p. 13.

${ }^{69}$ State governments (and sometimes local governments) impose income taxes in the United States, Canada, and other federal systems; See Shah, supra note 8, pp. 105, $142,161,330$, and 355 . 
capacity to reach significant numbers of taxpayers although the same taxpayers may be subject to state and/or local income tax jurisdiction. In Ethiopia, that is not really the case. The federal government cannot, through the income taxes, reach farmers, cooperatives, businesses organized as sole proprietorships, employees of state governments and employees of private enterprises. With these taxpayers beyond the reach of the federal income tax system, can the federal government be effective in its stabilizing and distributive role? It is once again very doubtful. ${ }^{70}$

Both stabilization and distribution are not matters of immediate concern in Ethiopia, however, for at least two reasons. First, interpersonal distribution of income and wealth is not an important policy in Ethiopia because of the level of the country's economic development. In the future, as the economy grows, it may become an important agenda of the federal government. Secondly, there have not been divergent regional tax policies so far- the reasons of which have been alluded to above. There is a rule in the Federal Financial Administration Law $^{71}$ which enjoins regions to harmonize their tax policies and systems with that of the federal government. It is not certain if the federal government can invoke this law as binding upon the regions because it is not after all the Constitution. So far, the regional governments are moving in perfect sync with the federal government. As far as the Constitution is concerned, there is no reason why regional governments cannot adopt a counter-federal tax policy. That can create problems down the line in the areas of stabilization of the economy and distribution of income and wealth.

\section{Concluding Remarks}

The revenue provisions of the Ethiopian Constitution are marked by their unusual specificity. It is surmised that the existing taxes at the time of the writing of the Constitution provided the drafters with the material from which the assignment was undertaken. The schedular approach of the Ethiopian income tax system, for example, had something to do with the way the Constitution divided revenue powers over income taxes in Ethiopia. The specificity of the Constitution is both good and bad. It is good because little is left for interpretation. The great details of the Constitution have this advantage:

${ }^{70}$ Since the Constitution follows similar approaches with respect to other taxes (notably sales taxes), our doubts may even increase as we add more taxes into the mix.

${ }^{71}$ See the Federal Government of Ethiopia Financial Administration Proclamation, $15^{\text {th }}$ year, No. 56, Article 64(1) ; the repealed Federal Financial Administration Proclamation contained an identical prescription of tax harmonization; see Federal Government of Ethiopia Financial Administration Proclamation No. 57/1996, Federal Negarit Gazetta, $3^{\text {rd }}$ year, No. 14 (now repealed and replaced), Article 58. 
in most cases it is clear which layer of government has what tax powers. That does not mean that there will be no disputes, but the disputes that can possibly arise in this regard have been considerably reduced owing to the specificity of the Constitution.

However, details in a constitution can have downsides, because it may arrest substantive tax reforms. As a result of the specificity of the Constitution, it is now almost inevitable that any serious tax reform at the national level must be accompanied or preceded by a measure of constitutional amendment to accommodate tax reform proposals. Constitutional amendment processes are notoriously slow and riddled with uncertainties. If the amendments are perceived as reorganizing taxation powers in the Constitution, for example, they are going to be resisted particularly if opposing political forces occupy either the federal bodies or the regional governments. The possible transition of Ethiopian income tax system from a schedular to a global tax system is used as an illustration of the gravity of the question, but the same argument can be made for reform of the tax system in so many other directions.

The revenue provisions of the Ethiopian Constitution can also be faulted for disregarding the dictum of fiscal federalists that taxes which are instruments of stabilization and distribution be in the hands of the federal government. The revenue provisions have devolved certain stabilizing or redistributing taxes to the regional governments. There is therefore fear that the federal government may not have enough powers on the tax side to effect desirable economic policies. The realization of this fact may again call for constitutional amendment, which, as pointed out earlier, is not easy to get through.

Finally, a disclaimer is in order. The argument put forward in this article may be misconstrued as an argument for centralizing certain powers or even worse concentrating powers in the hands of the federal government. Nothing of that sort is intended. All that the article calls for is the reorganization of certain tax powers without in any way diminishing the powers of the regions in the federal system of Ethiopia, but by meanwhile conferring adequate revenue powers upon the regions. 